\title{
Kafka's uncle: scenes from a world of trust infected by suspicion
}

Iain Bamforth General Practitioner, Strasbourg, France

\begin{abstract}
What happens when we heed a call? Few writers have been as suspicious of their vocation as Franz Kafka (1883-1924). His story, A Country Doctor, (1919) ostensibly about a night visit to a patient that goes badly wrong, suggests a modern writer's journey to the heart of his work. There he discovers that trust, like the tradition which might sustain him, is blighted. This essay also examines Kafka's attitude to illness and the medical profession, and his close relationship with his uncle, Siegfried Löwy (1867-1942), a country doctor in Moravia.

( 7 Med Ethics: Medical Humanities 2000;26:85-91)
\end{abstract}

Keywords: Franz Kafka; German literature; trust; suspicion; doctor-baiting; negotiation

\section{1}

After working for a year as a country doctor in Scotland, I came across a slim pale-green hardback, and read it during my first winter away from home. It was a bibliophile edition of Franz Kafka's Ein Landarzt (A Country Doctor) published by the small Berlin press, Wagenbach to celebrate thirty years in business.

The history of the book is a striking reminder of Kafka's almost entirely posthumous fame as a writer. Written mostly in his sister Ottla's apartment in the famous Alchemists' Lane in Prague as "the war to end all wars" turned to disaster for the Austro-Hungarian Empire, Ein Landarzt appeared in January 1920, and received a single notice in the Prager Tagblatt newspaper. It was a flop, as were the other six titles published by Kafka in his lifetime.

Like the original, this new edition of the stories is printed in the large typeface Kafka preferred-so large in the Walbaum Antiqua typeface of the first edition that hyphens had to be halved and punctuation marks omitted to fit the line. Kafka's writings, which often expand a single seamless paragraph into an entire story, make the large format suddenly, obviously necessary: it edges the reader into an assault on the size of thoughts themselves.

2

Kafka dedicated his book to his father. According to his friend Max Brod, his father is supposed to have muttered "put it on the table by my bed"; Hermann Kafka's refusal to acknowledge his son's literary activities is hardly one of the secrets of a well documented fraught relationship. But the title figure of the collection-the country doctorhonours a different relative altogether, his uncle.

Siegfried Löwy was born in 1867, elder half-brother to Kafka's mother and, following his $\mathrm{MD}$, possessor of the only doctorate in the family until his nephew. Significantly, Franz often thought of himself as a Löwy rather than a Kafka: his diary entry for 25 December 1911 contains a long list of colourful matrilineal begats, including a reference to his maternal great-grandfather, who was a miracle rabbi. "In Hebrew my name is Amschel, like my mother's maternal grandfather, whom my mother, who was six years old when he died, can remember as a very pious and learned man with a long, white beard. She remembers how she had to take hold of the toes of his corpse and ask forgiveness for any offence she might have committed against him. She also remembers his many books which lined the walls. He bathed in the river every day, even in winter, when he chopped a hole in the ice for his bath." ${ }^{2}$

In Letter to His Father he defined himself as "a Löwy with a certain Kafka component which, however, is not pushed ahead by the Kafka will to life, business and conquest, but by a Löwyish spur that works more secretly, more diffidently and in another direction, and which often fails to work entirely". ${ }^{3}$ One of the Löwyish spurs was his TB, which he described as if it were a conspiracy of organs: "Sometimes, it seems to me that my brain and lungs came to an agreement behind my back. Things can't go on this way, said the brain, and after five years the lungs said they were ready to help." ${ }^{4}$ Even the unpleasant transformation of the travelling salesman, Gregor Samsa, in Kafka's most famous story, Metamorphosis, into a hundredfooted insect covered with "sticky stuff" seems morphologically related to his illness: the repulsive appearance of the insect (which assures his victimisation) is in fact an inside: an eventrated respiratory tract replete with cilia and mucus carpet.

A doctor of law he might have been in life, but Kafka's real doctorate was handed down by an imaginary guild, the Faculty of Concepts to Live and Die By. Despite Koch's demonstration of the bacillary nature of tuberculosis in 1882, Kafka always interpreted his illness as a metaphor: what power could a bare fact have against a death sentence issued at birth? 
3

While his nephew was in his last years at school, Uncle Siegfried took up a post in Triesch, a small town of 4,800 inhabitants in a German-speaking enclave in Moravia called Iglau (Jihlava in Czech), about 130 kilometres south-east of Prague. It boasted several small industries including wool and spinning factories, and a mine. He was to practise there for close on forty years.

Siegfried Löwy was a liberal and man of his times; open to change and innovation, he created a sensation in the district when he became one of the first people in what was then an outpost of the Austro-Hungarian empire to acquire a motorbike. Franz came visiting in his summer holidays, the great attractions of staying with Uncle Siegfried being his horses, the billiard table and the library, which contained all the German classics. There were also the mechanical appliances - a photograph in the book shows his nieces, including Kafka's sister Ottla, push-starting Uncle Siegfried on his bike across a forest path.

According to the head conservationist of the motorcycle department of the Deutsches Museum in Munich, the tin panniers and distinctive rear shock absorbers identify it as a NSU Cantilever, built in Ulm between 1909 and 1914: NSU (better known as Audi) was one of more than fifty motorcycle manufacturers in the Europe of that time. (Schuetze C. Personal communication, 30.8.1996.) Since the world speed record was set on this machine in 1909, it may well be that Kafka's uncle read about the exploit and ordered a mode for his practice rounds. It would no doubt have served for a little talking behind his back in Triesch.

\section{4}

Unlike Kafka's father, the self-made man, Uncle Siegfried seems to have indulged Franz, and offered him help and advice at several junctures. He was "progressive" in his medical thinking too. On his recommendation Franz became a vegetarian, and for a time practised the obscure double-chewing technique recommended by the American physician Fletcher (1849-1919) along with Müller's free air gymnastic techniques (developing the body was a cult, of course, long before the Nazis made it a key element of their cultural propaganda).

"Fletschern" and "müllern", as they were rudely described, were the alternative therapies of the early 1900s, and Kafka seems to have hoped that regular cud-chewing and callisthenics would help deflect his conviction that his illness was prefigured-as if it had been inscribed on his body. "My body is too skinny for its weakness, it hasn't the least bit of fat to produce a blessed warmth, to preserve an inner fire, no fat on which the spirit could occasionally nourish itself beyond its daily need without damage to the whole."

Uncle and nephew both travelled together to the German North Sea islands of Heligoland and Nordeney after Franz completed his school exams. Much later, in February 1924, in the last months of his nephew's life, when he was living a vie de bohème in Berlin with a young Jewish girl from the eastern marches called Dora Dymant (or Diamant, as she called herself after emigrating to Britain before the war), his uncle visited him and persuaded him to enter a sanatorium. This was the happiest period of Kafka's life, according to Brod. Kafka wrote to Dora's orthodox Yiddish-speaking father, asking for permission to marry her: the rabbi prudently said no. Brod was a tireless friend, arranging for Uncle Siegfried to visit because doctors' fees were proving too expensive: Dora mentions having to pay 160 crowns for a house visit whereas Kafka's invalidity pension amounted to only 1,000 crowns a month.

Siegfried Löwy continued to practise in his house in Triesch until his retirement, when he moved to Prague and lived in the large house in the Bilkova left by Hermann, Franz's father, with his niecesthe Kafka sisters, Elli, Valli and Ottla-and their families. The night before the extended family was due to be deported to the death camps in 1942, Siegfried Löwy drew up his will and injected himself with a lethal dose of morphine.

\section{5}

His nephew's story, A Country Doctor, seems to be goaded on by its semicolons.

According to the literary critic Walter Benjamin, who recorded their conversation in Sweden while both were on the run from the Nazis in the 1930s, Bertolt Brecht, famous for his agit-prop theatre, accused Kafka of having the "precision of an imprecise man: a dreamer" Country Doctor how Brecht could formulate such a dismissive statement, even if he does resort to Kafkaesque method to do so. Kafka uses simple grammatical markings to establish layers of apparently banal realism in which bizarre things happen as matter of fact.

The first sentence announces "I was at my wit's end: an urgent journey lay before me", the colon buffers the adjoining sentence, in which five semicolons marshall the subordinate clauses into separate stretches of time and action and necessity. The American writer Nicholson Baker has called the semi-colon "that supremely self-possessed valet of phraseology" ; and the literary critic Erich Heller once drew attention to a "profound" semicolon in a remark by the philosopher Wittgenstein: "The philosopher treats a question; like a disease" where the profundity turns on whether the semicolon plays the comma and makes the questioning itself a kind of disease.

Kafka had an idiosyncratic system of notation when writing early versions of his stories in his notebooks. He used only commas and periods; semicolons were added only when the work was being prepared for publication. But perhaps the semicolon is more actively conspiratorial than Baker's "valet status" suggests: commenting on his friend Isaac Babel's laconic stories, Sergei Eisenstein, the Russian film director said-speaking of what literature could teach the cinema-"no iron 
can enter the human heart with such stupefying effect as a period placed at just the right moment".

If periods are bullets, then Kafka's semicolons are spurs edging one phrase recklessly on to the next, and barely holding them all in check.

\section{6}

It all starts with the narrator, the country doctor, at wit's end-“in a dwam" as Scottish country people say. A reportedly ill patient is awaiting his visit in a village ten miles off. He bemoans his lack of transport, his own horse having just died in the terrible winter weather. "But you just don't know what you're going to stumble across in your own house," says the servant girl. ${ }^{9}$

In the shortest possible grammatical time, the doctor has come across a groom, two horses which squeeze through the keyhole (they squeeze out of a pig-sty, a reference to the treatment reserved for the string of horses in the novella, Michael Kohlhaas, by the 19 th century writer Kleist ${ }^{10}$ ), abandoned his maid to the groom's designs on her, and arrived through a snowstorm in a flash at his patient's bed. The miraculous transport is itself described in a sentence with no less than eleven semicolons. It is a breakneck, lightning-speed journey which has a precedent in Hasidic stories: Kafka would have known these from the famous collection published by the philosopher Martin Buber, in which the Ba'al Shem-tov (the honorary title of Rabbi Israel ben Eli'ezer, the founder of Hasidism) is summoned to perform wonder cures at the drop of a hat. ${ }^{11}$ The Yiddish writer Isaac Bashevis Singer's later stories are full of such dropped hats.

For Kafka's doctor, however, any idea of a wonder cure is sheer parody. Already the patient is whispering into his ear, "Let me die". At first glance there's nothing wrong with him; as the doctor gets ready to leave he notices a wound near the hip seething with what look like larval forms of the house-fly Musca domestica. Another tradition-the Greek, in the story of Endymion and Selene-tells us the fly was once a beautiful, if excessively talkative girl; and since so many other half-hidden things are happening, we could be forgiven for thinking the patient laid low by the seeds of love.

Some critics have thought his wound syphilitic rather than tubercular, or even a kind of self castration; in any case it is impossible to miss the equation of the maid Rose and the horribly pink gap in the skin: metonymically the wound is the maid. "Will you save me?" pleads the patient, having evidently changed his mind. Under his breath, the doctor berates the community for its loss of belief; people are always expecting the impossible from the doctor's healing hand. Then a posse of villager elders arrives at the house with the school choir and teacher at its head, and sing a simple song denouncing doctors:

"Strip him naked, then he'll heal us And should he fail to, kill him quick! Only a mediciner, only a mediciner."
Stripped of his clothes, they lift the doctor on to the bed, "on the side of the wound". His patient complains about having to share his bed, but the doctor reassures him: such wounds aren't uncommon in the wide world. It seems to be a case of Munchhausen's syndrome, a couple of selfmutilating blows with an axe. Then it's time for him "to think of escaping".

He runs from them, the children chanting in the distance: "Now be cheerful, all you patients, Doctor's laid in bed beside you!" In contrast to his coming, his going is at a snail's pace. Fleeing his patients, unsure whether he'll get back home, his maid seized by the groom, his (shaman's) fur coat out of reach, the doctor's closing words are no less extraordinary than the entire story: "Betrayed! Betrayed! Respond to a false alarm on the night bell-and it can't be made good, ever again."

Despite doing his duty, morally and professionally - indeed striving to fulfil it in sectarian conditions seemingly bent against him-he ends up stripped of authority, in bed with the patient; and even then might not get home because he has dared upset the natural order (despite asserting that he is "no world reformer"). He fears, with some justification, that he is likely to be "misused for sacred purposes". Whatever he has done, effect and cause are disjoined: Gregor Samsa's offence, in Metamorphosis, is even less an operation of the will-he merely has to wake up to find he is what he dreamed he was.

Menaced, outmanoeuvred, and threatened by the massed ranks of the community, the hapless country doctor bears more than a passing resemblance to the epithet-title for the honest man in Henrik Ibsen's suggestively named drama, $A n$ Enemy of the People.

\section{7}

Kafka offers us a pathetic sight, a parody of uprightness: a doctor stripped bare by his patients. "Certainly doctors are stupid, or rather, they're not more stupid than other people but their pretensions are ridiculous; none the less you have to reckon with the fact that they become more and more stupid the moment you come into their clutches...", he reassures Milena Jesenská early on in their correspondence. ${ }^{12}$

His diary entry for 5 March 1912 portrays the kind of bullishly insensitive doctor whose attitude to his patient (presumably she couldn't afford his full fee) has survived fairly intact into the era of can-do medicine, where he may be more of a menace: "These revolting doctors! Businesslike, determined and so ignorant of healing that, if this businesslike determination were to leave them, they would stand at sick-beds like schoolboys. I wish I had the strength to found a nature-cure society. By scratching around in my sister's ear Dr K turns an inflammation of the eardrum into an inflammation of the inner ear; the servant collapses while getting the fire going; with the fleet diagnosis which is his wont in the case of serving staff, the doctor declares it an upset stomach and a resulting congestion of 
the blood. The next day she takes to her bed again, has a high fever; the doctor turns her from side to side, confirms it is a throat infection, and runs away so that the next moment won't refute him. Even dares to speak of the 'vulgarly violent reaction of the girl', which is true to this extent, that he is used to people whose physical condition is worthy of his curative power and is produced by it, and he feels insulted, more than he is aware, by the strong nature of this country girl."."13

Kafka is anatomically incorrect in attributing his sister's ear infection to the interfering Hausartz, but the "ignorant of healing" comment strikes hard. Having consulted more than a few doctors in his time, Kafka was no doubt used to being treated by them as if his body were merely a fleshy appendage to his lungs - those "proud strong tormented imperturbable creatures". His diary is peppered with his symptoms ("a new headache of a kind unknown so far", "I had a slight spell of faintness", "this past week I suffered something like a breakdown"), watched over with the fastidiousness of the true hypochondriac.

In June 1914, well before he first coughed up blood (which he experienced, significantly, as a kind of relief: "actually, my headaches seem to have been washed away with the flow of blood"), he had written to Grete Bauer: "undoubtedly an enormous hypochondria, which however has struck so many and such deep roots within me that I stand or fal with it". Observant of the theatrical aspects of his uncle's practice, and of the euphemistic sounds of doctors in general ("catarrh of the apex of the lungs"), ${ }^{4}$ Kafka sets the country doctor up for what doctors routinely subject their patients to but undergo rarely themselves, and then only by peers, as humiliation and primal fear: defrocking.

\section{8}

Being familiar with doctors who suffer diseases for their patients in folk stories, how, we might wonder, forgetting that $A$ Country Doctor was written in the early days of psychoanalysis, could a doctor suffer a wound for his patient? Is he being punished for impatience, his own and the spurs of those opening semicolons? Half a century before Michel Foucault "deconstructed" the power relations of the medical profession, Kafka identifies the surgeon's able hand as dispensing with the need for the confessional, the banished cleric sitting down desolately to unrave his raiment. It is a felt negative: the redundant cleric embodying the collapse of religious belief heralds the fall of the country doctor too.

Doctor-baiting has long been a clandestinely popular activity in country regions. Despite the onslaught of progress and professionals with black bags it still enjoys a vogue in some parts of the world. In country areas, where people have long memories, it is still remembered that doctors themselves were once a sort of plague.

The writings of David Rorie (1867-1946), an Aberdeenshire doctor who collected folk nostrums in rural Fife and Aberdeen, show that doctors have only ever been one of several possible sources of reassurance in the parish, and that the transmission of learning and knowledge have often had to work counterintuitively against common sense. It is not just a Scottish phenomenon. Indeed, Emanuel Strauss's extraordinary Dictionary of Proverbs tells us that every European language has its saws against the saw-bones, all of them variations on the theme "errores medicorum terra tegit" (physicians' faults are covered with earth). ${ }^{14}$

I don't know if Uncle Siegfried had to go out on a snowy night to answer a call (surely he did), but the ditties quoted by Kafka in the story seem inspired by him. He was, by all accounts, a self-deprecating joker-quite unlike Kafka's father. Kafka described him to his friend Max Brod as the "twitterer""because such an inhumanly thin, bachelor's, birdlike wit comes piping out of his tightened throat, and never abandons him". The story's most quoted phrase- "Writing prescriptions is easy, but for the rest, coming to an understanding with people is hard" 15 - has the ring of the horse's mouth, indeed seems to propel the whole story, which on one level is simply an enactment of a misunderstanding. Since prescription writing in German is cognate with what cooks do in the kitchen-recipe writing (Rezepte schreiben) being indisputably more art than science- - the country doctor's fate seems to depend on the unpredictable second half of the saying, on the burden he carries to make himself understood. This is clearer in the original, where the reflexive German verb imposes just such a condition on its grammatical subject (sich verständigen). ${ }^{16}$

These days, doctors "negotiate" with their patients, just like Kafka's doctor; and contemporary patients can be just as vague about what it was they wanted help with in the first place. Remove the plea for help, and the doctor has no business being where he is. Kafka underdetermines his stories to such an extent that potential meanings multiply alarmingly when the reader, anxious for the solid ground of interpretation, attempts to place the narrative in a context he himself has supplied.

My interpretation would be this. Nothing is harder to touch than the reality of our lives, and Kafka's rider might be: hardest of all for doctors.

\section{0}

Kafka's story does have anthropological parallels. The writer Elias Canetti recorded the following observation by the explorer Alexander von Humboldt. "In thirteenth-century Egypt, a mania for eating human flesh raged through all classes; doctors were the favourite prey. If a man was hungry, he feigned illness and sent for a doctor-not to consult him, but to devour him." This is confirmed with a note from a Baghdad physician's description of his travels - and travails - in Egypt: "people used all possible dupes to waylay others or lure them into their homes on false pretenses. Three doctors who visited me later met with this fate ... ${ }^{17}$ 
True or not, these stories replicate the internal dynamic of $A$ Country Doctor very convincingly. Perhaps our hero was lucky to escape at all, having had his nose rubbed in the presumption of wanting to help. Kafka often portrayed buffoons in his writings; they were beasts of meaningful burden for him as much as they were for the philosopher Nietzsche, who once wrote that fools were a disguise for "desperate, all too certain knowledge". ${ }^{18}$ That would make Kafka's uncle a kind of Shakespearean nuncle. Some of the most famous English cartoons-Hogarth's and Rowlandson's-lampoon doctors in Kafka's terms, as buffoons whose ministrations were a menace to the bodies of their patients. Perhaps folly and wanting to heal come from the same stable; and little wonder if in his moment of adversity the diagnostician, clumsy as he is, has no tradition to shelter in. In a letter to Gerhard Scholem in 1938, Benjamin wrote, as part of a critique of Brod's queasily sanctifying biography of Kafka: "This much Kafka was absolutely sure of: first, that someone must be a fool if he is to help; second, that only a fool's help is real help. The only uncertain thing is whether such help can still do a human being any good."19

\section{1}

As in so many of his stories of individuals unmanageably thwarted by forms of the life they lead in society at large, Kafka himself seemed to weigh criteria for success in a dimension where language bears a different charge of trust. Famously dissatisfied with his gifts as a writer, he confided to his diary shortly after finishing the story, that he could still derive "passing satisfaction from works like $A$ Country Doctor" provided he could continue to write such things at all; and happiness only if he could raise the world into "the pure, the true and the immutable".

The genius of $A$ Country Doctor - and it may be a malign one-resides in the fact that Kafka describes, without naming it, one of the pressing issues of his society - all the more so of our mediamanipulated "risk society": the issue of trust. It is disquieting that a man like Kafka, who worked in an insurance office, should have thought safeguards were hardly worth the paper they were written on. His village in the snow is a world of faith abruptly infected by the language of suspicion. The only strongly individuated character in the story, the doctor, is exposed to a witch hunt. Should we be surprised at the tribal, scapegoating logic that pursues him? Only if we fail to recognise that scandal is a secular society's last link with religion, and that trust gets depleted-like any non-renewable precapitalist resource.

Perhaps it is this worry which accounts for the lurch into cosmic anguish at the end of the story"and it can't be made good, ever again".

Every writer since the Enlightenment has been aware of being condemned to work in this atmosphere of suspicion, so mercilessly diagnosed by Nietzsche and Marx: without a craft tradition (the production and supply of articles needed by the community) creative work becomes painful, questing, inward, and often absurd. Trust for writers like Kafka is a primal state which can be regained by an act of will: that is why he wrote "nothing is granted to me, everything has to be earned, not only the present and the future, but the past, too". Or it can be seized by blind obedience; and Kafka's family history shows how ruthlessly a world of will and illusion was exploited by Hitler, whose inversion of the moral order received shamefully wide support from the "caring" profession. ${ }^{20}$ At the close of Kafka's century this quality of trust has eroded further, not just in the artist's despair about "doing art", but in the citizen's uncertainty about those "substantial categories of state, family and destiny". Not to speak of the doctor's dilemma.

Concluding his recent book on trust, the critic Gabriel Josipovici provides a warning and a message of hope: "But what the art and thought of the past two hundred years teaches us is not the lesson the deconstructionists and post-Modernists would draw from it, a lesson of our freedom to live as we want, to choose the stories and traditions we want to live by, the lesson of the hopeless entanglement of all culture and language in hidden struggles for power; it is, rather, that it is not possible to exist without trusting, that to walk and talk and, a fortiori, to write and paint and compose is only possible because of trust. When we grasp this we grasp too that denying trust is denying life itself as something that has to be lived in time and in the world of others, the world into which we have been born and in which we will die."21

\section{2}

In his last months Kafka didn't expect much of his own doctors. "Verbally I don't learn anything definite, since in discussing the tuberculosis ... everybody drops into a reticent, evasive, glassy-eyed manner of speech", he wrote to a friend from the sanatorium at Kierling, near Vienna, in April 1924.

He'd been brought there by his medical student friend Robert Klopstock, appalled at how he had been treated by Professor Hayek, the imperious ENT specialist who was to operate that same year, with nearly disastrous results, on Freud's oral cancer. That month Kafka weighed a mere 43 kilos (for a height of $180 \mathrm{~cm}$ ). His TB was now extrapulmonary: it had colonised his larynx, which was acutely inflamed, and from there spread to his epiglottis, effectively preventing him from nourishing himself. Coughing and swallowing must have been searingly painful. "To think that at one time I could simply dare to take a large gulp of water", ${ }^{22}$ he wrote on one of the slips of paper he handed to his friends, under doctors' orders to talk as little as possible.

Those same doctors injected phenol into the superior laryngeal nerve in an attempt to provide relief from pain, but the procedure was only partially successful. He wrote to his parentswonderful, affectionate, cheerful letters published only a few years ago, after their chance discovery by a Prague bookseller. ${ }^{23}$ In them he recalls the swimming lessons his father had given him, the beer and 
sausages after, and he makes no reference to what he had formerly called "the disgrace of showing myself undressed in public". This, a letter about drinking beer, when he was literally dying to have a drink of water but couldn't because of his painful throat! He wanted, at all costs, to avoid worrying his parents into visiting him. Dora was there all hours, desperate for the slightest hint of an improvement. He corrected the galley proofs of A Hunger Artist, which had just arrived from the publishers. One of the several notes he wrote, perhaps a wry reflection on Hayek's retinue of medical assistants, was collected and published after his death by Klopstock. It read: "So the help goes away again without helping."

To the end, Kafka retained his lucidity: he has left us one of the most blackly funny Jewish doctor jokes ever made: "Kill me", he instructed Klopstock, with whom he had arranged long in advance for a dose of morphine when nothing else availed, "or else you're a murderer".

\section{3}

Many of Kafka's stories are explicitly concerned with the individual's relationship to the community (The Investigations of a Dog; The Chinese Wall; fosephine, the Singer); the enthusiasm he spasmodically feels for communal life, like his response to the troupe of Yiddish actors he saw in the 1910s, is fed by his criticism of what the writer does, feeding on the marrow of his race, doing "research" as his sleuth-hound has it. He turns suspicion on himself. Brecht might have scorned his exactly dreamed precision, but he also noted that Kafka had all the attributes of a great teacher: without a society to inspire his Confucianism ended up as "mere" literature. Kafka noted this about himself too: writing to his fiancée Felice he said: "If I were Chinese ... but indeed I am Chinese". ${ }^{24}$

Everything is weighed in terms of what we might call its social utility value, and writing is found wanting. Doctoring too. To the villagers in the background of $A$ Country Doctor the figure represented by the doctor, despite his apparen bond to their common life, is not that far removed from the criminal and miscreant: he rides across the social order, he flaunts his individuality, his opinions are dissentient. The country doctor mimes solidarity with tradition even while knowing his acts follow another kind of logic altogether. His sense of impending persecution is the touchy tone heard so often in the confessions and letters of Jean-Jacques Rousseau, assertive even while it complains: Rousseau was one of literature's great back-biters, and father to Kafka's conviction that the forms and conventions of civilised life occasion many of our ills.

In fact, the doctor's moral vanity makes him more of a target. He would seem to be brother to the man on the rack in The Penal Colony, Kafka's terrible story of the condemned man whose sentence is gouged into his body: the instrument of torture is a Gutenberg printing press.
14

It strikes me that the patient on the bed bears his wound like the Biblical Jacob who, after wrestling the night through with the angel on the mountain, feels he has to ask the angel to curse him. Something similar crops up in Kafka's first significant piece of writing, The fudgement (1912), ${ }^{25}$ in which the seemingly invalid father hooks up his shirt, aping his son's fiancee, and displays his "war wound". His act of indecent exposure seems calculated to call into question his son's very manhood. Kafka mentions a similar episode in his travel diaries. Planning to visit Paris in October 1910, he was forced to stay in Prague due to a severe attack of furunculosis, boils on his backside; and writes "a brief fainting spell deprived me of the pleasure of bawling the doctor out. I had to lie down on the sofa, and during that time-it was very odd-I felt so much like a girl that I tried with my fingers to tug down my skirt".

The "wound", in fact, was Kafka's word for the experience of writing: his first story forced him to recognise his origins as a writer: he was one of those self-doubters, like his great predecessor, the Danish theologian Søren Kierkegaard, who kept open "the wound of the negative" so that trust might close it again -in some kind of natural healing process. Kafka's, however, was a mortal wound, since, as he wrote to Max Brod, a writer "dies (or doesn't really live) and is perpetually sorry for himself". ${ }^{26}$

Most disconcertingly of all, for those of us who trust Kafka as a writer, is the extraliterary dimension his writing has acquired. $\mathrm{He}$ is now a prophet. J P Stern once pointed out that there is a resemblance between Kafka's description of the wound and the use of natural metaphors in anti-Semitic propaganda, the most blatant being a passage in Hitler's Mein Kampf where he talks about "the leech on the Nation's body" ${ }^{27}$ What is so often interpreted as his clairvoyancy is surely Kafka's ability to take stock phrases and grasp them with the mental equivalent of the country doctor's forceps: not as crude metaphor, but as words of literal intent, however much they try to hide-like the hapless patient's wound-in full view.

\section{5}

These days the country doctor's model patient can be found in any old family: he's probably looking forward to being able to walk again in a few weeks now his hip is a vanadium/titanium sphere bonded to his femoral shaft, for a good fifteen years, with biocompatible epoxy resin. Writing to Brod from the sanatorium in the Erzgebirge just after he had completed A Country Doctor in 1917, Kafka dwells at length on his uncle's imperturbable cheeriness and aptitude for life in the country, and suggests that such a life might have tempted him once too"the way a slight rustling madness can make a person contented, thinking it the melody of life" ${ }^{28}$ But at 34, with questionable lungs and even more questionable relationships, he decides he has no right to such an expectation. And besides, flight from the 
paternal line is in that desire; the compelling nocturnal spectacle of Hope grappling with his Father.

Perhaps only the anorexic Kafka could have dignified his beefy middle-aged dad in such a way, as if he were calling the toss with the Wrestler of Genesis, "who touched the hollow of Jacob's thigh in the sinew of the hip". ${ }^{29}$

\section{6}

The wound had done its work. It was a moribund man who rehearsed a normal life with Dora in the last few weeks of the only life he had. "Franz is cheery and in good shape", ${ }^{30}$ appends Dora to one of his last letters; and a simple country doctor might wonder at the affection with which he addresses his parents, especially the father he made stand in so often as tormentor; at how he comes to accept his body and his manhood, even as his illness, and not its metaphor, kills him.

As for his uncle, we have a story which sees through him: the photograph reproduced in the Wagenbach book has him sitting on a metal skeleton of about 20 horsepower, his thighs urging it forward, his knuckles clenched on the throttle; while four female helpers including Kafka's favourite sister Ottla - the one who had encouraged Franz so much to quit the parental house in Prague, and had sustained him with regular food-packets in his last months with Dora in Berlin-smile triumphantly through the long exposure time for what may well have been Uncle Siegfried's gadget of a camera too.

In the photo Uncle Siegfried's NSU Cantilever is actually resting on its rear stand-poised for a moment in time, like the four human figures, on its own two legs.

\section{Acknowledgement}

I would like to thank Dr Christian Schütze and Herr Hans Strasse, Head Conservationist of the Motorcycle Department of the Deutsches $\mathrm{Mu}-$ seum, Munich, for their invaluable cooperation.
Iain Bamforth is a General Practitioner in Strasbourg, France.

\section{References}

1 Kafka F. Ein Landarzt: Kleine Erzählungen. Berlin: Verlag Klaus Wagenbach, 1994.

2 Kafka F. In: Brod M, ed. The diaries. Harmondsworth: Penguin, 1982: 152 .

3 Kafka F. Collected writings. London: Secker, 1976: 558.

4 Gilman S. Franz Kafka, the Fewish patient. New York: Routledge, 1995: 182 .

5 Benjamin W. Understanding Brecht. London: Verso, 1983:108. 6 Baker N. The size of thoughts, essays and other lumber. London: Chatto, 1996: 71 .

7 Heller E. The importance of Nietzsche. Chicago, University of Chicago Press, 1988: 142

8 Babel I. Collected stories. Harmondsworth, Penguin, 1994: 345.

8 Babel I. Collected stories. Harmondsworth, Penguin, 1994: 345. Kafka F. A country doctor. Translated by Iain
Fournal of General Practice 1999;49:1035-9.

10 Kleist H. Selected writings. Translated by David Constantine. London: Dent, 1997: 209-80.

11 Sadeh P. König Salomos Honigurteil. Munich: Hanser, 1989

12 Kafka F. Letters to Milena. Harmondsworth: Penguin, 1983: 26.

13 See reference 2: 191.

14 Strauss E. Dictionary of European proverbs. London: Routledge, 1998: 1143.

15 See reference 9: 1037

16 Bamforth I.Coming to an understanding with patients and prepositions [letter]. BMF 1997;314:1905-6.

17 Prepositions [letter]. BMF 1997;314:1905-6.

17 Canetti E. The human province. London: Deutsch, 1985.

18 Stern JP. Impatience. London Review of Books 1990;11:18. Benjamin W. Max Brod's
London: Fontana, 1973: 147.

20 Hanauske-Abel HM. Not a slippery slope or sudden subversion: German medicine and National Socialism in 1933 $B M F$ 1996;313:1453-63.

21 Josipovici G. On trust: art and the temptation of suspicion. New Haven: Yale University Press, 1999: 273-4.

22 Josipovici G. Writing and the body. Text and voice, essays 1981 1991. Manchester: Carcanet, $1992: 250$.

23 Kafka F. Briefe an die Eltern aus den Fahren 1922-24. Frankfurtam-Main: Fischer, 1993

24 Kafka F. Letters to Felice. Harmondsworth: Penguin, 1978: 594.

25 Kafka F. The judgement. Wedding preparations in the country and other stories. Harmondsworth: Penguin, 1982: 115.

26 Heller E. Frank Kafka. Princeton: Princeton University Press, 1982: 61.

27 Stern JP Hitler: the führer and the people. London: Fontana, 1984: 230

28 See reference 1: 78 .

29 Holy Bible. Genesis xxxii, 25.

30 Kafka F. Briefe an die Eltern aus den Fahren 1922-24. Frankfurtam-Main: Fischer, 1993. 